\title{
Applying token economy to improve attention of child with ADHD
}

\author{
Nora Devi Irianjani, Faridah Ainur Rohmah \\ Faculty of Psychology, Universitas Ahmad Dahlan, Indonesia \\ E-mail: noradevii@yahoo.com
}

\author{
Article History \\ Submitted: March 17, 2020 \\ Accepted: May 10, 2020 \\ Published: May 12, 2020 \\ DOI: $10.26555 /$ jecce.v3i1.1926
}

\begin{abstract}
A child should be able to pay attention well during task working. But, children with Attention Deficit Hyperactivity Disorder (ADHD) experience difficulty in focusing attention or in concentrating when doing a task, both at home or at school. In the other hand, there is a behaviour modification technique that effectively proven in increasing concentration of child with ADHD. The purpose of this study was to find out the effectiveness of token economy in improving the attention of children with ADHD when completing a task. The present study employed a single subject, a five years-old male Early Childhood Education student. The intervention was given in the form of token economy for two weeks through cooperation with parents. Observation and interviews were held to collect data regarding attention difficulty in engaging in the learning process and doing a task. The result of the study showed that there is an improvement in attention duration; the subject was able to give attention to the task in a longer duration (more than 5 minutes). The parents are expected to be more assertive and committed to applying token economy at home.
\end{abstract}

Keywords: ADHD, attention, token economy

\section{Abstrak}

Seorang anak harus dapat berkonsentrasi dengan baik selama proses mengerjakan tugas. Namun, anak dengan Attention Deficit Hyperactivity Disorder (ADHD) mengalami kesulitan dalam memusatkan perhatian atau berkonsentrasi selama mengerjakan tugas baik di rumah maupun di sekolah. Di sisi lain, terdapat suatu teknik modifikasi perilaku yang terbukti efektif dalam meningkatkan konsentrasi anak dengan ADHD. Penelitian ini bertujuan untuk melihat efektivitas penerapan teknik token ekonomi yang merupakan salah satu teknik modifikasi perilaku untuk meningkatkan atensi anak ADHD dalam mengerjakan tugas. Penelitian ini menggunakan subjek tunggal yakni seorang anak laki-laki berusia 5 tahun yang bersekolah di PAUD. Intervensi yang dilakukan kepada subjek yakni teknik token ekonomi selama 2 minggu dengan bekerjasama dengan orang tua. Observasi dan wawancara dilakukan sebagai alat pengumpulan data terkait kesulitan atensi dalam mengikuti proses belajar dan mengerjakan tugas. Hasil penelitian menunjukkan terdapat peningkatan jumlah durasi atensi dalam proses mengerjakan tugas pada anak ADHD, yaitu anak dapat memberi perhatian dengan waktu yang melebihi sebelumnya. Rekomendasi untuk orangtua diharapkan dapat lebih tegas dan berkomitmen dalam melaksanakan token ekonomi.

Kata Kunci : $A D H D$, atensi, token ekonomi 


\section{INTRODUCTION}

The case number of Attention Deficit Hyperactivity Disorder (ADHD) is quite high in Indonesia. Data Center and Health Information of Republic Indonesia shown that in 2017 mental health discussion was positioned at ranked 5 of health issue with percentage of $13.4 \%$ , while ADHD was positioned at rank 10 of mental health issue (Indryani \& Wahyudi, 2019). Theoretically, ADHD prevalence is about $1-5 \%$ of the population and males risked four times higher than females in showing the symptoms (Santrock, 2007). A systematic review indicates that the community prevalence globally is between $2 \%$ and $7 \%$, with an average of around $5 \%$. It means that at least $5 \%$ of children in a country have substantial difficulties with overactivity, inattention and impulsivity which are some symptoms of ADHD (Sayal et al., 2018). A study conducted in Kecamatan Padang Timur, Indonesia shows that the prevalence of children with ADHD is $8 \%$, while the comparison number between males and females is $2: 1$. Specifically, children aged 11-13 years old are at highest risk in experiencing ADHD. This disorder causes difficulties in paying attention, controlling impulsive, and hyperactive behavior (Novriana et al., 2014).

Children with ADHD are characterized by a lack of focus, aggressive, and tend to be destructive, excessive energy, purposeless movement, and impatience. ADHD is a condition with a pervasive condition of attention, followed by hyperactivity and impulsivity as the adherent. However, this symptom can only be detected before seven years, and this occurs in various situations such as school, playground, or other social situation (Baihaqi \& Sugiarmin, 2006). Children with ADHD tend to have average or above-average cognitive abilities, however, their achievements are often below their potential. Their low achievements caused by a failure in participating and remembering the instruction (Davidson, 2010).

ADHD deals with a gen-related issue, virus, problems during pregnancy, and intervention that causes brain tissue damages (Wahidah, 2018). Besides, focus/hyperactivity disorder is also affected by the social environment and parenting style. Improper /Unguided use of audio-visual information technology, such as gadget, can be a factor that plays a role in complicating the symptoms. A study shows that parenting style is moderator in co-occurrence 
of ADHD symptoms with other psychopathology in young adults. That suggests that parenting style may effects of ADHD risks (Ni \& Gau, 2015).

In order to train the skill and personality of children with ADHD to have better selfadjustment, a considerable amount of attention is required. Children with ADHD can be success if they manage to adapt to their surroundings. Accordingly, in order to lower long-term risk, proper treatment is needed. The treatment is made in order to decrease pervasive issues of children with ADHD, such as low social skills, which leads to low self-esteem, depression, low academic achievement, and emotional problems.

One of the evidence-based treatments for children with ADHD is behavior modification (DuPaul et al., 2012). There are five techniques, namely positive reinforcement, token economy, time out, extinction, and punishment. In this study, the technique that was applied was token economy. Token is one of applied techniques of operant conditioning. Using token economy, the intervention is aimed to transform maladaptive behavior into adaptive behavior (Corey, 2007). In its process, the environment plays a role in organizing reciprocal relationship between behavior and its consequence.

In this case, behaviorism paradigm is applied. Behaviorism is an approach that emphasizes on observable behavior, not on awareness (Kring et al., 2012). The behavior of the subject who suffers attention disorder/hyperactivity can be known based on the observation result. This disorder is unconsciously manifested in the form of observable behavior.

Behavior approach focuses on identifying antecedent, behavior, and consequence, which are known as function analysis (Ollendick, 1998). Antecedent refers to any matter that triggers the behavior and is associated with certain situations. Behavior refers to the problematic behavior, including frequency, intensity, and duration. Consequence refers to responses or result of the behavior. Consequence can also maintain the problematic behavior.

Behaviorism sees abnormal behavior as a learned response, is responded in the same ways with other behaviors (Kring et al., 2012). The behaviorism learning principle applied in this case is operant conditioning. Operant conditioning is a reinforcement principle by expecting the target behavior to be repeated or removed (King, 2010). Operant conditioning explains that the reaction of operant behavior, either positive or negative reinforcement, may repeat or remove the behavior. 
In this study, token economy is expected to modify target behavior through conditioning and reinforcement. As stated by Ayllon \& Azrin (Miltenberger, 2003), token economy may strengthen the target behavior after it occurs immediately. It is an easy process for both giver and recipient, where the recipient may learn various abilities as target behavior. Applying token economy may reinforce the target behaviors. Gift or reinforcer indirectly serves as attempt to reinforce the target behavior. Gifts can be in the form of sign, sticker, or token. The gifts can be exchanged in certain period. It is expected that the target behavior can be achieved and maintained (Corey, 2007).

There are some previous studies showing that giving token economy to children with ADHD may lower unfavorable behavior in classroom and may improve academic performance. Token economy can be used to increase the attention duration of children with ADHD in completing school tasks (Mulyani, 2013). The reinforcement or token that is made in an interesting form, and is directly given to children may motivate them to repeat the target behavior. This conditioning is expected to maintain the behavior target (Mulyani, 2013). In another study, relationship between token economy found a significant result, meaning that token economy can be used to enhance academic performance in completing task faster and reducing annoying behavior of children with disability (Muzdalifah, 2019).

Based on some studies, it was found that token economy is used as an alternative intervention to reduce maladaptive behavior, especially on children. Token economy applies the giving of token economy that can be exchanged with the gift or direct reinforcement (Mulyani, 2013). Gift can be categorized into primary and secondary forms. The primary form of gift includes food, money, toys, while the secondary form includes compliment or attention. Giving gift in the form of token economy may repeat the targeted behavior (Reed \& Martens, 2011). It is expected that token economy can remove maladaptive behaviors and changes it with more adaptive behavior by utilizing mark or sticker (Kaplan \& Sadock, 2006).

Based on the description above, the researcher is interested in studying the application of token economy to improve attention of child with ADHD. The purpose of this study was to find out the effectiveness of token economy in improving the attention of children with ADHD. Psychoeducation for parents is aimed to provide them with an understanding of positive 
parenting before applying token economy intervention. It is expected to be able to support the intervention process. Indicators that can be used to determine positive parenting (Sanders, 2008) are: 1) understanding the child's condition, 2) understanding the cause of child's behavior, 3) creating and adhering to the schedule without putting pressure to the child, 4) providing safe environment for child to explore, 5) responding positively while interacting with children, 6) holding discussion with children about the rule, 7) trying to keep calm and thinking positively when facing child's behavior.

\section{METHOD}

This study employed single case design with pre-post test without control group. The measurement was carried out before the treatment, during the treatment, and after the treatment using anecdotal record and interview. Content analysis was used. This study applied token economy as the intervention, the single subject was treated with reinforcement in order to achieve the targeted behavior (i.e attention of child with ADHD). In general, the procedure of the study involve the presentation of assessment result and intervention technique as designed in table 2.1. In session I, the intervention was in the form of psycho education related to positive parenting for the parents, in session II, token economy was applied for 2 weeks, and in session III, weaning process is done.

Table 2.1. Intervention design

\begin{tabular}{|c|c|c|c|c|}
\hline Session & Form of Intervention & Purpose & Tool & Target \\
\hline I & Psycho education & $\begin{array}{l}\text { Provide the parents } \\
\text { with understanding } \\
\text { about positive } \\
\text { parenting }\end{array}$ & Paper and pen & Parents \\
\hline II & $\begin{array}{l}\text { The implementation of } \\
\text { Token Economy }\end{array}$ & $\begin{array}{l}\text { Train the subject to } \\
\text { maintain } \\
\text { concentration for } 10 \\
\text { minutes for two weeks. }\end{array}$ & $\begin{array}{l}\text { 1. Board } \\
\text { 2. Star sticker as } \\
\text { the token } \\
\text { 3. Gift }\end{array}$ & Subject \\
\hline III & Weaning & $\begin{array}{l}\text { Train the subject to } \\
\text { improve adaptive } \\
\text { behavior and reduce } \\
\text { maladaptive behavior } \\
\text { through the weaning } \\
\text { process }\end{array}$ & $\begin{array}{l}\text { 1. Board } \\
\text { 2. Star sticker as } \\
\text { the token } \\
\text { 4. }\end{array}$ & Subject \\
\hline
\end{tabular}

In this study, token economy was applied to modify target behavior. Token economy is one technique of behavior modification which effectively proven by some researches to form 
desirable behavior especially in children with ADHD (Fiyati, 2019; Hayati, 2019; Mulyani, 2013; Rahmawati, 2013). Token as conditioned reinforcer given to subject to perform desirable behavior that is paying attention while working on tasks. Those tokens can be redeemed with some interesting gifts for subject. Table 2.2 shows baseline behavior to give an idea about starting behavior of the subject before the intervention began. Target behavior determined as standard for subject to gain the tokens. Later, subject could redeem those tokens for some gifts in a certain amount.

Table 2.2. Token Economy Application Target Behavior

\begin{tabular}{cccc}
\hline No & Baseline behavior & Target behavior & Types of Token \\
\hline 1. & $\begin{array}{c}\text { Subject is able to } \\
\text { concentrate for } 5 \text { minutes }\end{array}$ & $\begin{array}{c}\text { Subject is able to } \\
\text { concentrate for } 7 \text { minutes }\end{array}$ & 4 stickers \\
\hline 2. & $\begin{array}{c}\text { Subject is able to } \\
\text { concentrate for } 5 \text { minutes }\end{array}$ & $\begin{array}{c}\text { Subject is able to } \\
\text { concentrate for } 10 \\
\text { minutes }\end{array}$ & 6 stickers \\
\hline
\end{tabular}

Consequence was also applied in order to prevent counterproductive behavior. Subject would lose two stickers when performing hyperactive behavior such as running, jumping, shouting, and hitting. In the end of intervention, subject redeemed the tokens with interesting gifts that are mentioned at table 2.3.

Table 2.3. List of Gifts of Token Economy

\begin{tabular}{ccc}
\hline No & Score Token & Gift \\
\hline $\mathbf{1}$ & 10 & Toy car \\
\hline $\mathbf{2}$ & 30 & Favorite book \\
\hline $\mathbf{3}$ & 50 & Pencil case 'Tayo' \\
\hline $\mathbf{4}$ & 70 & Play in kids fun \\
\hline
\end{tabular}

Psychoeducation about positive parenting, particularly effective communication, included giving clear and simple instruction, understanding child's condition and cause of child's behavior, creating a schedule and adhere to the schedule without putting pressure in to make the child motivated, providing a safe environment to allow the child to explore, providing positive response when interacting with the child to minimize labeling, not comparing the child to others, commitment and consistency regarding the rule to be applied, and avoiding the use of inappropriate language. Those processes highly require parent-child 
collaboration. Accordingly, the parents are expected to keep calm and have positive thinking when facing child's behavior.

The treatment is combined with positive reinforcement in the form of smile and compliment when the subject is able to show the expected behavior. The environment manipulation is done by setting aside other things when the subject is studying or doing a task. The monitoring was done by the parents. The parents would monitor and remind when the subject begins to be distracted by other activities during the task. Monitoring is also done on weekly basis (i.e., every Sunday) to see the effectiveness of the program.

In this study, the subject was a 5-years old ECE student with ADHD in Warungboto, Yogyakarta. The data were collected through direct observation, this was done in at least two different settings. Besides, interview with the parent and the teacher were also conducted. The general observation was done by making anecdotal records that revealed the physical, cognitive ability, emotion, social interaction, and communication skills. It was then followed by observation based on ADHD symptoms described in PPDGJ III.

The visual analysis technique was employed by directly analyzing the data as per condition (Baihaqi \& Sugiarmin, 2006). Psychological tests were conducted in the form of cognitive test in order to find out the subject's cognitive numerical ability, test graphic in order to find out the subject's personality related to cognitive, emotional, and social matters. These tests were done to confirm the criteria of intellectual ability that supports the diagnosis of children with ADHD.

The assessment was also done through two-weeks observation to determine the baseline of target behavior (i.e., concentration). Baseline refers to the initial condition without any treatment. Determining baseline is important since it becomes the basis for comparing the intervention success. After determining the baseline of target behavior, the next step was the implementation of token economy and monitoring. Once token economy is given, the monitoring process begins. Consistency of the target behavior is the basis to determine the weaning process. The purpose of the weaning process is to prevent the subject's dependence of gift or reinforcement. 


\section{RESULT AND DISCUSSION}

Based on the two-weeks observation before token economy was given, it was found that the baseline behavior (i.e., subject's concentration) could last for 5 minutes. Accordingly, the program was designed to train subject to be able to concentrate for 10 minutes when completing a task. The intervention that was given for two weeks in general can enhance the subject's concentration from 5 minutes to 13 minutes. The subject was able to control his behavior when his parents reminded him, thus, his hyperactive behavior decreased. In addition, the subject was also willing to do the task without any excuse. As shown in table 3.1 subject was able to increase duration in concentrate with the tasks.

Table 3.1. Result of Token Economy Phase I (First 2 weeks)

Before intervention

Subject is able to concentrate for 5 minutes

Subject is able to concentrate for 7 minutes

\section{After intervention}

Subject is able to concentrate for 7 minutes Subject is able to concentrate for 13 minutes

The subject begins to be motivated when he knew there would be a gift for achieving a target. The subject's motivation becomes greater when receiving temporary reinforcement as shown in table 3.2.. This was supported by the parent's compliment. The subject once refused and cried when his tokens mother took two of his tokens due do shouting and jumping in chair. The mother had reminded the subject to do in accordance with the initial agreement. In general, token economy was effective in improving the subject's concentration. The subject was able to maintain the concentration for 10 minutes in two weeks.

Table 3. 2. Evaluation of Token Economy Phase I (First 2 weeks)

Before intervention

The effect of token economy on subject's behavior is still known.
After intervention

Economy token run quite well, shown by the consistency of the targeted behavior.

Unmotivated to improve attention.

Fairly stable/consistent motivation to improve attention.

The supporting factor during the implementation of PSDB was collaboration between the subject and the parent. Besides, the subject was also well-motivated in participating in the program. The hindering factors of the intervention were that the mother sometimes forgets to immediately give the token. However, the subject still tries to achieve the next behavior target. 
In addition, the mother always asked the subject to stick the token together. Table 3.3. shows that parents were involved in the intervention and were able to collaborate to monitor subject's behavior. Psychoeducation for parents was essential for this intervention so that they understand the way token economy behavior modification works.

Table 3.3. Token Economy Weaning Phase I (First 2 weeks)

\section{Before intervention}

The parents had not been trained in reducing and increasing child's maladaptive behavior, accordingly, subject's maladaptive behavior occurs often.

Parents had not understood the way to monitor the child,development.

\section{After intervention}

Parents were trained in reducing and increasing child's maladaptive behavior, the child thus was able to change maladaptive behavior into adaptive behavior.

Parents were able to collaborate to monitor child's development.

ADHD is an attention disorder followed by hyperactivity and impulsivity. The subject of this study begun to exhibit ADHD symptoms since he was one-year-old. Those symptoms emerge in various situations such as home, school, public place such as minimarket, and playground. ADHD deals with gen-related issue, virus, problems during pregnancy, and intervention that causes brain tissue damages (Wahidah, 2018). Besides, focus/hyperactivity disorder is also affected by social environment. The use of audio-visual technology (e.g. gadget) during childhood also complicates the syndrome. One of the causing factors of ADHD is an inconsistent parenting style. Based on the assessment result, it becomes one of the cause of disorder, the subject had operated gadget when he was a child. Besides, the parent's inconsistent parenting complicated the disorders.

In this case, behaviorism paradigm is applied. Behaviorism is an approach that emphasizes on observable behavior, not on awareness individual (Kring et al., 2012).The behavior of the subject who suffers attention disorder/hyperactivity can be known based on the observation result. This disorder is unconsciously manifested in the form of observable behavior.

Behavioral approach focuses on identifying antecedent, behavior, and consequence, which are known as function analysis (Ollendick, 1998). Antecedent refers to any matter that triggers the behavior, and is associated with certain situation. Behavior refers to the problematic behavior, including frequency, intensity, and duration. Consequence refers to responses or result of the behavior, consequence can also maintain the problematic behavior. 
Behaviorism paradigm see abnormal behavior as a learned response, is responded in the same ways with other behaviors (Kring et al., 2012). The behaviorism learning principle applied in this case is operant conditioning. Operant conditioning as a process of reinforcing operant behavior so that the behavior can be repeated or omitted (King, 2010). In this principle, operant behavior reinforcement is done in the form of positive or negative reinforcement, which can cause the individual's behavior to be repeated or omitted. In this case, the subject's response had not been consistent, accordingly, the subject still showed improper behavior repeatedly.

Based on behaviorism approach, the intervention that can be given to child with ADHD is behavioral therapy using token economy. Token economy as a concept applying operant conditioning by changing direct gift with something that can be exchanged later (Mulyani, 2013). Gift can be categorized into primary and secondary form. The primary form of gift includes food, money, toys, while the secondary form includes compliment or attention. Giving gift in the form of token economy may repeat the targeted behavior (Reed \& Martens, 2011). Token economy aims to remove maladaptive behavioral pattern and changes it with adaptive behavioral pattern (Kaplan \& Sadock, 2006).

Some previous studies showed that giving token economy to children with ADHD may lower improper behavior in classroom and may improve the academic performance. Study showed that token economy can enhance concentration of child with ADHD in completing tasks (Mulyani, 2013). Besides, the form of interesting reinforcement or token that is directly given may motivate the child to repeat the expected behavior and increase the habit to maintain the target behavior. Another study showed that token economy can increase the concentration ability so that the child requires fewer time and can reduce maladaptive behavior of children with learning disabilities (Aziz \& Yasin, 2018)

The supporting factors during the intervention process in this study were the subject's willingness to participate in the intervention process, the motivation to increase target behavior, parent's willingness to play a role, and monitor the subject's behavior (i.e., attention when completing the task). The parents play important role through effective communication. Effective communication consists of giving clear and simple instruction, motivating, no labeling, no comparing, clear commitment and consistency regarding the rule to be applied, 
and avoiding bad language. The parent's characteristics that supported the intervention process are patience and understanding. The hindrance during the intervention was the parent's inconsistency in treating and responding the child's behavior.

\section{CONCLUSION}

Based on the result of the study, it was found that applying token economy may improve attention of child with ADHD. The child's consistency in performing token economy is in line with the improved target behavior (i.e., attention). The parent's commitment to give token economy right after the target behavior appears may motivate the child to show the expected behavior. The higher the parent's commitment, the higher the child's motivation to achieve target behavior.

The advantages of token economy are that the reinforcement may motivate the subject to achieve target behavior, may increase discipline and increase more effective communication patterns between child and parent. The weaknesses of token economy is that the parent's tendency of inconsistency in monitoring child's behavior. Besides, it is time-consuming because in order to reach the weaning process, the target behavior should emerge consistently. Child's unstable motivation is also one of weaknesses of token economy. In addition, improper application may result in dependence, where the children are only motivated to do something for a reinforcement or gift. However, in this study, it has been anticipated by weaning so that it is expected that the child does not depend on reinforcement or gift.

\section{REFERENCES}

Aziz, N. A. A., \& Yasin, M. H. M. (2018). Token Economy to Improve Concentration among Students with Learning Disabilities in Primary School. Journal of ICSAR, 2(1), 32-36. https://doi.org/10.17977/um005v2i12018p032

Baihaqi, M., \& Sugiarmin, M. (2006). Memahami dan Membantu Anak ADHD. PT. Refika Aditama.

Corey, G. (2007). Teori dan Praktek Konseling dan Psikoterapi. PT. Refika Aditama.

Davidson, G. C. (2010). Psikologi Abnormal. Rajawali Press. 
DuPaul, G. J., Eckert, T. L., \& Vilardo, B. (2012). The Effects of School-Based Interventions for Attention Deficit Hyperactivity Disorder: A Meta-Analysis 1996-2010. School Psychology Review, 41(4), 387-412. https://doi.org/10.1080/02796015.2012.12087496

Fiyati, S. U. (2019). Konseling Islam melalui token ekonomi dalam upaya meningkatkan konsentrasi belajar pada seorang anak ADHD (Attention Deficit Hyperactivity Disorder) di SLB C Kemala Bhayangkari 2 Gresik [Undergraduate, UIN Sunan Ampel Surabaya]. http://digilib.uinsby.ac.id/29185/

Hayati, R. (2019). Token Ekonomi pada Anak dengan Gangguan ADHD. Eksistensi, 1(2), Article 2. https://doi.org/10.29406/eksis.v1i2.1690

Indryani, Y. A., \& Wahyudi, T. (2019). Situasi Kesehatan Jiwa di Indonesia. Pusat Data dan Informasi Kementerian Kesehatan Republik Indonesia.

Kaplan, H. I., \& Sadock, B. J. (2006). Kaplan dan Sadock; Sinopsis Psikiatri; Ilmu Pengetahuan Perilaku Psikiatri Klini. Binarupa Aksara.

King, L. A. (2010). Psikologi Umum: Sebuah Pandangan Apresiatif. Salemba Humanika.

Kring, A. M., Johnson, S. L., Davidson, G., \& Neale, J. M. (2012). Abnormal Psychology Twelfth Edition. Wiley.

Miltenberger, R. G. (2003). Behavior modification (Principles and Procedures) (5th ed.). Wadsworth Cengange Learning.

Mulyani, R. R. (2013). Penerapan token ekonomi untuk meningkatkan atensi dalam mengerjakan tugas pada anak ADHD. Psychological Journal: Science and Practice, 1(1), Article 1. http://202.52.52.22/index.php/pjsp/article/view/1343

Muzdalifah, R. (2019). Efektivitas penerapan token ekonomi untuk meningkatkan konsep diri $\begin{array}{llll}\text { akademik siswa tunagrahita. Jurnal Ecopsy, } & \text { (2) }\end{array}$ https://doi.org/10.20527/ecopsy.v6i2.5902 
Ni, H.-C., \& Gau, S. S.-F. (2015). Co-occurrence of attention-deficit hyperactivity disorder symptoms with other psychopathology in young adults: Parenting style as a moderator. Comprehensive Psychiatry, 57, 85-96. https://doi.org/10.1016/j.comppsych.2014.11.002

Novriana, D. E., Yanis, A., \& Masri, M. (2014). Prevalensi Gangguan Pemusatan Perhatian dan Hiperaktivitas pada Siswa dan Siswi Sekolah Dasar Negeri Kecamatan Padang Timur Kota Padang Tahun 2013. Jurnal Kesehatan Andalas, 3(2), Article 2. https://doi.org/10.25077/jka.v3i2.52

Ollendick, H. T. (1998). Child Behavioral Assessment. Pergamon Press.

Rahmawati, K. R. (2013). Token Economy untuk meningkatkan atensi pada anak Attention Deficit Disorder. Procedia: Studi Kasus Dan Intervensi Psikologi, 1(1), Article 1. https://doi.org/10.22219/procedia.v1i1.1374

Reed, D. D., \& Martens, B. K. (2011). Temporal discounting predicts student responsiveness to exchange delays in a classroom token system. Journal of Applied Behavior Analysis, 44(1), 1-18. https://doi.org/10.1901/jaba.2011.44-1

Sanders, M. R. (2008). Triple P-Positive Parenting Program as a public health approach to strengthening parenting. Journal of Family Psychology: JFP: Journal of the Division of Family Psychology of the American Psychological Association (Division 43), 22(4), $506-$ 517. https://doi.org/10.1037/0893-3200.22.3.506

Santrock, J. W. (2007). Life-Span Development Perkembangan Masa Hidup Edisi Kelima Jilid I. Penerbit Erlangga.

Sayal, K., Prasad, V., Daley, D., Ford, T., \& Coghill, D. (2018). ADHD in children and young people: Prevalence, care pathways, and service provision. The Lancet Psychiatry, 5(2), 175-186. https://doi.org/10.1016/S2215-0366(17)30167-0

Wahidah, E. Y. (2018). Identifikasi dan Psikoterapi terhadap ADHD (Attention Deficit Hyperactivity Disorder) Perspektif Psikologi Pendidikan Islam Kontemporer. Millah: Jurnal Studi Agama, 17(2), 297-318. https://doi.org/10.20885/millah.vol17.iss2.art6 